\title{
МОДЕЛИРОВАНИЕ ИСТОРИИ РАЗРАБОТКИ АССЕЛЬСКОЙ ЗАЛЕЖИ ОРЕНБУРГСКОГО НЕФТЕГАЗОКОНДЕНСАТНОГО МЕСТОРОЖДЕНИЯ
}

Бапиев В.З., Кривина Т.Г., Назыров М.Р., Утробин Н.В.

\section{(ООО «ВолгоУралНИПИгаз»)}

Ассельская газонефтяная залежь является частњю нефтяной оторочки Оренбургского нефтегазоконденсатного месторождения, расположена в восточной части месторождения. Залежь введена в эксплуатацию в 1984 r, разрабатывается на истошение. $\mathrm{Ha}$ сегодняшний день эксплуатационный фонд скважин состоит из 60 скважин, из залежи отобрано более $20 \%$ запасов нефти.

При выполнении работы по пересчету запасов углеводородов в 2004 г. сформирована цифровая геологическая модель Ассельской залежи, которая представляет собой псевдо-трехмерную модель, состояпую из набора двумерных моделей слоев (пачек) залежи. Геологическая модель создана в пакете RM (Schlumberger GeoQuest). Гидродинамическая модель базируется на основе шифровой геологической модели и использует трехмерный трехфазный симулятор Eclipse 100.

Первоначально на модели проведены расчеты истории при разныг условиях управления скважинами:

- управление по суммарному объему продукции скважин в пластовых условиях;

- управление по отборам нефти.

Расчет с управлением по объемам пластовой продукции показал, что при существующих условиях вскрытия скважинами продуктивного пласта, расчетное соотношение добычн «газ-нефть-вода» существенно отличается от того, какое фиксируется в геолого-технических отчетах. Расчет с угравлением по объему добычи нефти приводит к значительному увеличению добычи газа и воды на модели.

Анализ данньх по вскрытьп интервалам эксплуатационных скважин выявил, что треть скважин (23 из 63) имеет интервалы перфорации, частично или полностью лежащие ниже водонефтяного контакта. В то же время 9 эксплуатационных скважин имеют интервалы перфорации, лежащие выше газонефтяного контакта.

При обосновании отметки ВНК в подсчете запасов указано, что по результатам интерпретации ГИС однозначно определить горизонтальное положение ВНК затруднительно в силу наличия переходной зоны, толщиной 10-20 м между чисто нефтяной и чисто водоносной частями залежи.

На гидродинамической модели с принятым положением водонефтяного контакта скважины, открытые интервалы которых лежат ниже отметки ВНК, дают воду, придем обводненность продукции (в целом по залежи) в расчетах достигает на сегодняшний день $41,6 \%$. На практике этого не наблюдается. Если же предположить, что интервалы, попадающие в водоносную часть, не освоены, и закрыть их для эксплуатационных скважин, то в расчетах такие скважины не в состояния выполнить фактическую добычу нефти.

Скважины, интервалы которых лежат выше газонефтяного контакта, дают в расчетах большое количество свободного газа, что тоже не подтверждается данными истории добычи. Результаты опробования скважин говорят о том, что газонефтяной контакт, возможно, был занижен.

Чтобы исключить оштбки, связанные с осреднением свойств на псевдо-трехмерной модели, построена детальная фрагментарная модель участка Ассельской залежи. Расчет истории на фрагментарной модели также показал несоответствие между соотношением запасов газа и нефти, историей добычи и динамикой падения давления в залежи.

При моделировании истории Ассельской залежи принято репгение задать абсолютную отметку ВНК на 10 м ниже утвержденного значения. Переходная зона над уровнем ВНК моделируется введением капиллярного давления на границе «нефтьвода». При этом в переходной зоне запасы нефти составили 34,7 \% от утвержденных запасов. Газонефтяной контакт моделировался нами на 5 м выше утвержденной отметки. Запасы нефти при этом увеличились на 7,7 \% от утвержденных запасов, запасы газа уменьшились на $28 \%$.

Такое решение не противоречит результатам опробования скважин и позволяет точно воспроизвести историю добычи нефти и воды, как на полномасштабной, так и на фрагментарной модели. Расчетная динамика падения пластового давления при этом согласована с фактической. Что же касается добычи газа, то она в геолого-технических отчетах явно занижена и отражает только растворенный газ, поэтому оценить правильность расчетов по добыче газа на модели затруднительно.

\section{Выводы}

Для корректного моделирования разработки Ассельской залежи необходимо:

- уточнение положения ГНК и ВНК и соотношения запасов нефти и газа;

- проведение замеров на промысле для определения объемов добываемого скважинами попутного газа;

- создание полномасштабной трехмерной модели Ассельской залежи. 